\title{
R-spondin1, WNT4, and the CTNNB1 signaling pathway: strict control over ovarian differentiation
}

\author{
Anne-Amandine Chassot $^{1,2}$, Isabelle Gillot ${ }^{1,2}$ and Marie-Christine Chaboissier ${ }^{1,2}$ \\ ${ }^{1}$ University of Nice-Sophia Antipolis, Parc Valrose, F-06108 Nice, France and ${ }^{2}$ UMR-INSERM1091, \\ IBV, F-06108 Nice, France
}

Correspondence should be addressed to A-A Chassot; Email: chassot@unice.fr or to M-C Chaboissier;

Email: marie-christine.chaboissier@unice.fr

\begin{abstract}
Sex differentiation is a unique developmental process. Starting from a bipotential gonad, it gives rise to the ovary and the testis, two highly specialized organs that differ morphologically and physiologically despite sharing common reproductive and endocrine functions. This highlights the specific plasticity of the gonadal precursors and the existence of complex antagonistic genetic regulation. Mammalian sex determination is controlled by paternal transmission of the Y-linked gene, sex-determining region $\mathrm{Y}$ (SR $\mathrm{Y}$ ). Using mouse models, it has been shown that the main role of Sry is to activate the expression of the transcription factor Sox9; either one of these two genes is necessary and sufficient to allow testicular development through Sertoli cell differentiation. Thus, defects in $S R Y / S r y$ and/or $S O X 9 / S o x 9$ expression result in male-to-female sex reversal of $X Y$ individuals. Molecular mechanisms governing ovarian differentiation remained unknown for a long time, until the discovery of the roles of R-spondin1 (RSPO1) and WNT4. In XX individuals, activation of the $\beta$-catenin signaling pathway by the secreted proteins RSPO1 and WNT4 is required to allow granulosa cell differentiation and, in turn, ovarian differentiation. Thus, mutations in RSPO1 result in female-to-male sex reversal of XX patients, and mouse models have allowed the identification of genetic cascades activated by RSPO1 and WNT4 to regulate ovarian development. In this review, we will discuss the respective roles of RSPO1, WNT4, and the $\beta$-catenin signaling pathway during ovarian differentiation in mice.

Reproduction (2014) 148 R97-R110
\end{abstract}

WNT4 and R-spondin1: state of the art

\section{$W N T / \beta$-catenin signaling and the ovary: a woman's story?}

It has long been assumed that the female outcome was the default state during sexual development. This came from the work of the endocrinologist Alfred Jost, who carried out castration experiments of rabbit embryos and observed that the external genitalia of both male and female fetuses developed as female (Jost 1947). As a result, the majority of laboratories focused their research on finding the molecular clues triggering male development. In the 1990s, the male-determining factor was discovered and it has been shown that male fate of the gonad depends on expression of the sex-determining region $Y(S R Y)$ gene, localized to the $Y$ chromosome transmitted by the father (Sinclair et al. 1990). While male differentiation began to be elucidated, the study of ovarian development received very little attention and remained quite mysterious. More recently, however, the view of a 'default' female pathway has been challenged by the description of genetic mutations leading to masculinization of XX gonads despite the absence of any 'male' genes in human XX patients (Parma et al. 2006, Mandel et al. 2008), in mice (Vainio et al. 1999), and in goats (Pailhoux et al. 2001). Most of these mutations affect the $\mathrm{WNT} / \beta$-catenin signaling pathway that controls various steps in mammalian organogenesis and organ homeostasis during adulthood (Niehrs 2012, de Lau et al. 2014). In 2006, Prof. Giovanna Camerino et al. identified R-spondin1 (RSPO1), a WNT signaling pathway activator, as a novel key factor involved in sexual and ovarian differentiation (Parma et al. 2006). After 2 years, Prof. Blanche Capel et al. showed that genetic induction of $W N T / \beta$-catenin signaling can modify the fate of the gonad by promoting the ovarian development from a gonad programed to become a testis (Maatouk et al. 2008). This complemented their previous work on Wnt4, another player in the WNT signaling pathway, which showed that sex determination is governed by a balance between two antagonistic pathways (Kim et al. 2006) and firmly established WNT/B-catenin signaling as a key pathway involved in female differentiation. In this review, we will discuss the role of WNT4 and RSPO1, the best studied WNT signaling activators in sexual differentiation. We will 
also report the data obtained in other species and discuss some of the key questions that remain to be answered.

\section{WNT4, a Wingless family gene involved in many biological processes}

The first Wingless gene was discovered in the 1970s in genetic screens aiming to identify genes essential for segment patterning of the Drosophila embryo. Since then, numerous studies have shown the implication of Wingless in a wide spectrum of biological processes. WNT family members (for Wingless-type MMTV integration site family) are highly conserved secreted glycoproteins. Although it was assumed that Wingless was a long-range acting protein, recent data have indicated that, at least in Drosophila, it acts predominantly on neighboring cells (Alexandre et al. 2014). In mammals, 19 secreted WNT ligands have been identified whose function entails binding to Frizzled receptors and LRP co-receptors ((Niehrs 2012) and references herein). Depending on the WNT ligand and its association with Frizzled and LRP, different pathways may be activated.

WNT3A is known to activate the so-called canonical $W N T / \beta$-catenin signaling pathway that eventually leads to stabilization of CTNNB1 ( $\beta$-catenin) and transcription of its targets. By contrast, other WNT proteins can induce CTNNB1-independent pathways including the planar cell polarity (PCP) and WNT/ROR pathways ((Niehrs 2012) and references herein). The cellular context is essential for the choice of the pathway to be activated as exemplified by WNT4. While WNT4 is able to activate canonical WNT signaling in gonadal development (Maatouk et al. 2008, Liu et al. 2010), it appears to induce CTNNB1-independent pathways in the kidney (Burn et al. 2011). In addition to its role in canonical WNT signaling, CTNNB1 is also an important component of adherent junctions, which regulates patterning and morphogenesis. This process is required for gonadogenesis (Fleming et al. 2012) and it has been suggested that WNT4 is involved in CTNNB1 relocalization to the cell membrane during ovarian development (Naillat et al. 2010).

In female patients, heterozygous missense mutations in the WNT4 gene lead to a syndrome characterized by the absence of uterine and fallopian tubes and clinical signs of excess androgen, indicating that WNT4 is required for female reproductive tract development (Biason-Lauber et al. 2004). In mice, Wnt4 has been shown to be important for multiple morphogenetic processes, including formation of the kidney, adrenal and mammary glands and the reproductive tract where it regulates endothelial and steroidogenic cell migration (Jeays-Ward et al. 2003), sex determination (Kim et al. 2006), and female development (Vainio et al. 1999).

\section{RSPO family: four members with a similar structure, activating different receptors and regulating various signaling pathways}

The activators of the WNT/ $\beta$-catenin pathway include RSPO proteins. A few years ago, Rspo1 (roof platespecific spondin) was the first member of the RSPO family to be identified from screening of genes specifically expressed in the developing spinal cord. It was named for its expression in the roof plate of the neural tube of the mouse embryo and the presence of a protein domain that shares homology with thrombospondin (Kamata et al. 2004). That same year, Xenopus R-spondin2 was isolated in a functional screen for its property to activate WNT signaling (Kazanskaya et al. 2004). Since then, numerous studies have focused on the RSPO family. This family comprises four members (RSPO1, RSPO2, RSPO3, and RSPO4) with pleiotropic functions in embryogenesis, development, and tumorigenesis (Yoon \& Lee 2012).

All four RSPOs are cysteine-rich (CR) secreted proteins containing a single thrombospondin type 1 repeat domain. The amino acid sequences of the RSPO proteins are highly conserved (40-60\%), especially within vertebrate species, and the four members of the mammalian RSPO family have a similar domain organization (Kamata et al. 2004, Kazanskaya et al. 2004).

Although RSPOs contain an amino-terminal signal peptide, these secreted glycoproteins remain associated with the cell surface (Kazanskaya et al. 2004). This suggests that RSPOs act mainly as juxtacrine factors. Nevertheless, the missing link for clarifying how RSPOs activate the WNT signaling pathway remained yet to be found. In 2011, it has been demonstrated that RSPOs stimulate WNT signaling by binding to the leucine-rich repeat-containing $G$ protein-coupled receptors LGR4, LGR5, and LGR6 (de Lau et al. 2011). RSPO can also bind the transmembrane RING-type E3 ubiquitin ligases ZNRF3 or its homolog RNF43, two negative-feedback regulators of WNT signaling leading to their clearance at the membrane level (Koo et al. 2012). Upon binding, degradation by ubiquitination of the WNT receptors can no longer occur and canonical WNT signaling becomes activated (de Lau et al. 2014). As RSPO1 can bind to ZNRF3 independent of LGR4, this suggests that RSPO1 could transduce WNT signaling without interacting with LGR receptors. However, RSPO1 binds ZNRF3 or RNF43 with a low affinity that is highly enhanced when RSPO1 is already bound to LGR. This implies that LGRs act as recruitment receptors for RSPOs at the membrane. The CR domain of RSPO is necessary and sufficient for this interaction ((de Lau et al. 2014) and references herein).

Moreover, RSPOs can also bind some cell membrane heparan sulfate proteoglycans such as syndecans. Thus, RSPO2 and RSPO3 bind syndecan 4 through their TSP domain (Glinka et al. 2011). In combination with 
WNT5A, this leads to the activation of the MAP kinase JNK and WNT/PCP signaling pathways during Xenopus gastrulation.

LGRs can also activate non-canonical WNT signaling including the WNT/PCP, G-RhoGTPase pathways (Glinka et al. 2011) and can act independent of RSPO (Fafilek et al. 2013). Whether RSPOs have receptors other than LGR remains yet to be elucidated.

\section{RSPO, a family of genes regulating morphogenesis and maintenance of numerous organs}

RSPOs are involved in both embryonic development and homeostasis of adult tissue in many species. Disruption of the human RSPO1 gene in a recessive syndrome is characterized by female-to-male sex reversal, palmoplantar hyperkeratosis, a predisposition to squamous cell carcinoma, corneal opacity, onychodystrophy, and seminoma (Parma et al. 2006, Tomaselli et al. 2008). This suggests that RSPO1 functions as a tumor suppressor. However, RSPO1 can act as a potent specific mitogen by promoting the proliferation of intestinal cells (Kim et al. 2005). During development, Rspo1 plays key roles in sex determination and ovarian differentiation (Chassot et al. 2008a, Tomizuka et al. 2008). Rspo1 has also been shown to be involved in mammary gland formation in mice and angiogenesis in zebrafish. In addition to its different roles in embryogenesis, this gene can also promote organ homeostasis, as evidenced by its role in $\beta$-cell neogenesis in the pancreas (Gore et al. 2011, Yoon \& Lee 2012).

The importance of Rspo2 in development has also been revealed by loss-of-function experiments. Indeed, null mutations of Rspo2 cause a variety of abnormalities in branchial arches, lungs, and limbs in mice (Yoon \& Lee 2012). Abnormal expression of RSPO2 or $R S P O 3$ has been identified in $10 \%$ of colorectal cancer cases (Wu et al. 2014). Moreover, RSPO2 can also induce proliferation of another epithelium, the epidermis during keloid scarring (Chua et al. 2011). Rspo3 ablation in mice is lethal at 10 days post coitum (dpc). Although this has led to the description of this gene's key roles in vasculogenesis, angiogenesis, and blood cell speciation (Kazanskaya et al. 2008), it has precluded, thus far, the analysis of its potential role in later development. The congenital mutations in RSPO4, the last member of the RSPO family, result in anonychia in humans (Blaydon et al. 2006).

In the future, it is likely that new physiological functions of RSPOs in organogenesis and maintenance of organs will be unraveled.

\section{Sex determination: two sexes, common progenitors}

Sex differentiation is a unique developmental process. Starting from an undifferentiated bipotential gonad, it gives rise to two very specialized organs, the ovary and the testis (Fig. 1). Initially, the morphogenesis of the gonadal primordium appears to be similar between male and female embryos, although the transcriptomic signature is different between both sexes in mice (Jameson et al. 2012a), in which the genital ridges are formed at $\sim 9.5 \mathrm{dpc}$ (reviewed by Svingen \& Koopman (2013)). Proliferation of coelomic epithelial cells, combined with the recruitment of precursor cells from the mesonephroi, leads to the outgrowth of future gonads. The early somatic precursors are specified and proliferate between 10.5 and $12.0 \mathrm{dpc}$, corresponding to

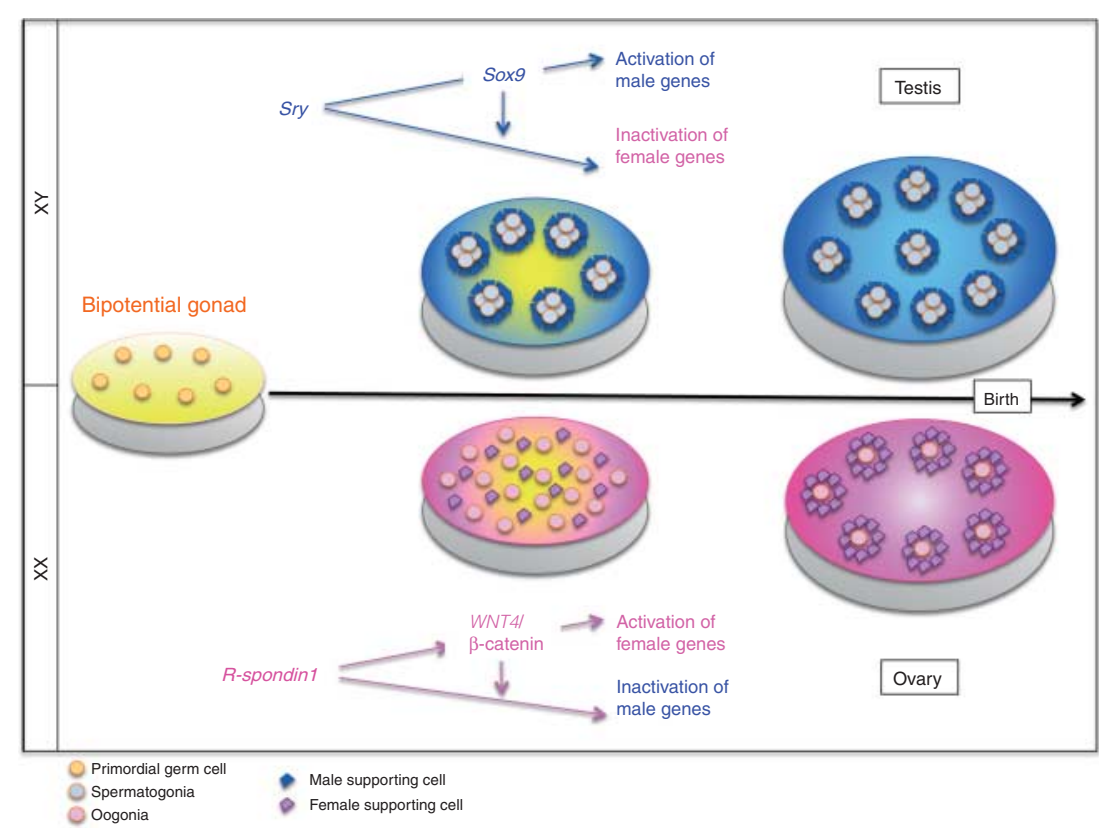

www.reproduction-online.org
Figure 1 Current model of sex determination. In the embryonic testis (top), Sry promotes Sox 9 expression, which in turn induces Sertoli cell differentiation. In fetal ovaries (bottom), RSPO1, a direct WNT4/ $\beta$-catenin pathway activator, regulates granulosa cell differentiation. Female genes are repressed while male genes are upregulated to trigger the development of a testis. By contrast, in the developing ovary, male genes need to be repressed, while female genes are upregulated (Jameson et al. 2012b). 
$\sim 6$ th week of gestation in humans (Schmahl et al. 2004). At this stage, the gonadal primordium is morphologically similar in male and female embryos. The cells localized to the coelomic domain delaminate and enter the underlying mesenchyme to differentiate into Sertoli or pre-granulosa cells, and a few interstitial cells in XY and XX gonads respectively (Karl \& Capel 1998). Thus, the supporting cell types, Sertoli cells in males and granulosa cells in females, stem from a common progenitor population present in the bipotential gonad before its commitment to a testicular or ovarian fate. In the same way, interstitial cell types, Leydig cells in males and theca cells in females, are thought to derive from a common progenitor (Albrecht \& Eicher 2001). Supporting and interstitial cell types are responsible for germ cell support and hormone production in the gonad.

In the gonadal primordium, the insulin/insulin-like growth factor (IGF) pathway promotes the expression of key genes involved in gonad formation and sex determination, such as the orphan nuclear receptor SF1 (Pitetti et al. 2013), also known as nuclear receptor subfamily group A member 1 (NR5A1). In turn, Sf1/ Nr5a1 expression controls the differentiation into gonadal precursor cells. Moreover, MAP kinase signaling cascades, especially p38MAPK and MAP3K4, lead to the expression of Sry specifically in the XY gonad (Warr et al. 2012). SIX1 and SIX4 transcription factors are also involved both in gonadal precursor differentiation through Sf1/Nr5a1 upregulation, and in Sry upregulation through direct regulation of Zfpm2 (Fog2) expression, a zing finger protein interacting with GATA4 to stimulate Sry transcription (Fujimoto et al. 2013).

Following Sry expression, a genetic cascade is induced, triggering a testis-specific wave of proliferation of pre-Sertoli cells. Together with SF1, SRY promotes the expression of another Sry-related HMG box (SOX) gene, Sox9. SOX9 induces Sertoli cell differentiation and, in turn, testis differentiation (Chaboissier et al. 2004, Sekido \& Lovell-Badge 2008). Their expression is then relayed by additional factors ensuring testis development ((Svingen \& Koopman 2013) and references herein).

\section{From the bipotential gonad to the ovary: roles of RSPO1 and WNT4}

In the bipotential gonad, the insulin family of growth factors and its related receptors are required for gonadal differentiation in both sexes (Pitetti et al. 2013). XX or XY embryos, deficient for both insulin receptor (Insr) and IGF receptor 1 (Igf1 $r$ ) genes, are characterized by smaller gonads that remain undifferentiated for several days before activation of the ovarian genetic program. In this delayed gonad, expression of Sf1 is decreased and proliferation of the somatic cell progenitors severely affected, indicating that the insulin/IGF signaling is participating in early proliferation of the somatic precursor cells (Pitetti et al. 2013). Similarly, ablation of both Six 1 and Six4 genes triggers the development of hypoplastic gonads, suggesting that they are also required for the proliferation of Sertoli or granulosa cell progenitors (Fujimoto et al. 2013).

Rspo1 and Wnt4 also participate together in the early coelomic proliferation and mutant mice, deficient for both of these genes (Rspo1 ${ }^{-1-} ; W_{n t 4^{-1-}}$ embryos), display a significant decrease in coelomic cell proliferation between 10.5 and $11.5 \mathrm{dpc}$ (Chassot et al. 2012). Nevertheless, Sf1 expression is not significantly downregulated in the $\mathrm{Rspo1}^{-/-} ; \mathrm{Wnt}^{-/-}$gonads, suggesting that RSPO1 and WNT4 act downstream of SIX1, SIX4, and SF1. Moreover, Wnt4 expression is significantly reduced in Insr; Igf1 r double mutant ovaries (Pitetti et al. 2013), implying either that Wnt4/Rspo1 expression depends directly on the insulin signaling pathway, or that the low level of Wnt4 expression indirectly results from decreased cell proliferation of Insr; Igf1r mutant gonads. However, Igf1r expression is strongly reduced in the Rspo1 ${ }^{-/-} ; W_{n t 4^{-/-}}$gonads (Chassot et al. 2012), suggesting that potential feedback interactions may exist between these two signaling pathways.

The proliferation defect of the $\mathrm{Rspo}^{-/-} ; \mathrm{Wnt}^{-1-}$ gonads is observed independent of the sex of the embryo. Nevertheless, this process is more severely impaired in mutant $X Y$ embryos than in mutant $X X$ embryos. In normal XX embryos, the pre-granulosa cells, which are devoid of Sry expression, display ovarianspecific upregulation of cell cycle inhibitors such as $\mathrm{p} 21^{\mathrm{kip} 1}, \mathrm{p} 57^{\mathrm{kip} 1}$, and $\mathrm{p} 27^{\mathrm{kip} 1}$ at 11.5 and $12.5 \mathrm{dpc}$, which may maintain their proliferation rates at a lower level than the proliferation of $X Y$ precursor cells (Cederroth et al. 2007). In addition, in XY embryos, proliferation of coelomic epithelial cells is activated following the expression of Sry and its downstream effectors, leading to an increase in testis size (Schmahl et al. 2004). Defects of proliferation in XY Rspo1 ${ }^{-1-}$; $W n t 4^{-1-}$ gonads lead to hypoplastic testis development.

As described above, RSPO1 is an activator of the $\beta$-catenin signaling pathway. Activation of the WNT/ $\beta$ catenin signaling pathway is detected in the coelomic epithelium of the bipotential gonad in $X Y$ and $X X$ embryos at $11.5 \mathrm{dpc}$, suggesting that WNT4/RSPO1 may activate proliferation of these cells through WNT signaling (Chassot et al. 2012). At this early stage, Lgr5, a recruitment receptor of RSPO1, and Lrp4, a WNT co-receptor involved in epithelial-mesenchymal cell communication during development, are specifically enriched in gonadal XY somatic precursor cells (Jameson et al. 2012a). However, one cannot exclude that RSPO1 and WNT4 act through different receptors. Nevertheless, no functional study of potential receptors has been carried out in the gonad and it remains to be shown that LGRs act as RSPO1 receptors in this organ. How RSPO1 
and WNT4 signal synergistically in the bipotential gonad remains another open question.

\section{Rspo1, Wnt4, and female sex determination RSPO1, WNT4, and WNT/ $\beta$-catenin signaling: an ovarian-specific activation}

At $12.5 \mathrm{dpc}$, Rspo 1 and Wnt4 expression becomes ovary specific (Vainio et al. 1999, Parma et al. 2006). RSPO1 and WNT4 are secreted by the somatic cells of the ovary. In addition, RSPO1 expression is detected at the membrane of both somatic and germ cells at 12.5 and $14.5 \mathrm{dpc}$ (Kocer et al. 2008, Smith et al. 2008), suggesting that it may act on both cell types (see below).

At $12.5 \mathrm{dpc}$, Wnt4 expression is abolished in the $R_{s p o 1^{-1-}}$ gonad, whereas Rspo1 expression is maintained in the $\mathrm{Wnt}^{-1-}$ gonad, suggesting that RSPO1/WNT signaling promotes the maintenance of Wnt4 expression (Chassot et al. 2008a, Tomizuka et al. 2008). This loss of Wnt4 expression might highlight abnormal differentiation of pre-granulosa cells.

Following Rspo1 and Wnt4 expression, WNT/ $\beta$-catenin signaling is activated in a sex-specific manner in somatic and germ cells of the ovary from $12.5 \mathrm{dpc}$ onwards, as evidenced by Axin2 expression, a universal activation marker for this signaling pathway (Chassot et al. 2011, Jameson et al. 2012a). In XY gonads, WNT/ $\beta$-catenin signaling is downregulated following Sry expression. Consistent with this observation, in vitro studies have shown that SRY can antagonize CTNNB1 by physically interacting with it at the protein level, thus targeting CTNNB1 to nuclear bodies, to trigger its degradation and inhibit CTNNB1-mediated transcriptional activity (Bernard et al. 2008). Nevertheless, this mechanism has not yet been confirmed in vivo during sex determination. Conversely, ectopic activation of CTNNB1 in XY somatic cells results in male-to-female sex reversal by disrupting the testis fate and promoting ovarian development. This study established that $\beta$-catenin signaling is a female-determining pathway (Maatouk et al. 2008; Fig. 1). However, the conditional knockout of Ctnnb1 in somatic tissue of the ovary does not impair ovarian differentiation (Manuylov et al. 2008, Liu et al. 2009), suggesting that either the ablation of Ctnnb1 must occur within all ovarian cell types (somatic and germ cells) to promote sex reversal, or Rspo1 and Wnt4 activate pathways other than the WNT/CTNNB1 signaling pathway.

It should also be noted that, in contrast to Axin2 $2^{+/ L a c Z}$ reporter, no positive staining was observed with the TOPGAL mouse model, another reporter line for $\beta$-catenin signaling (reporter lines are described by Barolo (2006)). TOPGAL mice carry three multimerized LEF/TCF consensus binding sites in front of the LacZ reporter, which may suggest that CTNNB1 in the developing gonad may act in a LEF/TCF-independent way (A A Chassot, unpublished data).

Rspo1 and Wnt4 control WNT/B-catenin activation in the $\mathrm{XX}$ gonads as evidenced by rescue experiments (Chassot et al. 2008a, Maatouk et al. 2008, Liu et al. 2010). However, in the absence of Wnt4 or Rspo1, Ctnnb1 transcriptional activity is only partially decreased as Axin2 remains expressed in the coelomic region of the XX gonads (Chassot et al. 2012), suggesting that there remain other positive regulators of WNT/ $\beta$-catenin signaling to be identified.

Sex determination is governed by two antagonistic pathways, taken together, involving, on the one hand, WNT signaling, which promotes female differentiation, and, on the other hand, Sry/Sox9/Fgf9, which activate male development (Sekido \& Lovell-Badge 2008, Jameson et al. 2012b, Lavery et al. 2012; Fig. 1).

\section{Lack of Rspo1 and Wnt4 both leading to partial sex reversal}

Human 46, XX SRY-negative patients carrying mutations in the RSPO1 gene display male-to-female sex reversal with hypospadia and hypogenitalism (Parma et al. 2006). Histological analysis of one gonad from another XX patient carrying an RSPO1 homozygous mutation revealed the presence of both testicular and ovarian tissues (Tomaselli et al. 2008), indicating that sex reversal was partial. Moreover, seminiferous tubules yield germ cell neoplasia and tumor cells were found in the stroma. The ovarian part contained corpora albicans, indicating the presence of a former follicle. Consistent with this finding, adult XX $\mathrm{Rspo1}^{-1-}$ mice display sex reversal and are characterized by ovotestes in which the testicular part, evidenced by the presence of male-like seminiferous tubules with Sertoli cells and interstitial tissue, can form the main part of the mutant gonad, giving it the appearance of a hypoplastic testis (Chassot et al. 2008b). Within the ovarian part, the presence of large abnormal cysts was noticed in 11-week-old mice (Chassot et al. 2008a). No tumors have been described in these mutant mice; this could be due, however, to genetic background susceptibility as shown for other mutant models (Cook et al. 2011).

Homozygous mutations of WNT4 in XX patients are associated with developmental defects such as renal and adrenal agenesis and female-to-male sex reversal (Mandel et al. 2008). Histological analysis of a 19-weekold 46, XX fetus revealed testicular development similar to a control testis, suggesting that complete sex reversal might have occurred. The gonad of another 24-week-old 46, XX affected fetus from the same family displayed partial sex reversal with both ovarian and testicular tissues. Both fetuses carried the same mutation affecting the stability of WNT4 mRNA, a fact that could explain the phenotypic variability (Mandel et al. 2008). In the Wnt4 mouse model, sex reversal with the appearance of 
cord-like structures is observed around birth. These testis cords are similar to those observed in Rspo1-deficient females and express male markers such as $\mathrm{DHH}$ and SOX9 (Vainio et al. 1999, Maatouk et al. 2013). However, in mice, no adrenal agenesis has been described. The differences between humans and mice may be due to functional redundancy between $W n t$ genes in mice. Wnt2b and $W n t 9 a$ are expressed in early gonadal development (Cederroth et al. 2007, Jameson et al. 2012a) and could activate WNT signaling in the absence of WNT4. Moreover, Rspo1 and Wnt4 are also involved in maintaining the quiescent state in pregranulosa cells after germ cells have entered meiosis ((Maatouk et al. 2013) and below). Their role at this later stage may account for the late appearance of sex reversal approximately at the time of birth, rather than at the time of sex determination.

\section{Absence of Rspo1 or Wnt4 stimulates a male-like vascularization of the gonad}

The first morphological abnormality observed in the XX $R s p o 1^{-1-}$ embryo is the presence of a blood vessel at $12.5 \mathrm{dpc}$ that is characteristic of male development. This coelomic vessel is usually formed at the surface of the embryonic testis and is required to pattern the gonad and guide sex cord formation (Cool et al. 2011). The malelike vasculature of mutant XX gonads suggests that Rspo 1 is required to inhibit the crosstalk between mesenchymal and endothelial cells. Interestingly, screening performed on isolated endothelial cells indicates that, at 12.5 and $13.5 \mathrm{dpc}$, Axin2 and known RSPO1 receptors, such as Lgr4, Lgr5, or Lgr6, are not expressed in this cell population (Jameson et al. 2012a), suggesting that RSPO1 acts independent of canonical WNT/ $\beta$-catenin signaling or indirectly in this context. Thus, the role of Rspo1 in vasculature development remains to be analyzed.

Wnt4 deficiency also induces male-like vascularization of the embryonic XX gonad. Jeays-Ward et al. (2003) demonstrated that WNT4 is required to antagonize both endothelial and steroidogenic cell migration from the mesonephros within the XX gonad, thus preventing the formation of the testis-specific coelomic vessel and the production of steroids. WNT4 is required to stimulate follistatin (Fst) expression. FST is an activin-binding protein expressed in the $\mathrm{XX}$ gonad from $11.5 \mathrm{dpc}$ onwards, whereas it is absent in $X Y$ gonad. FST is known to antagonize Activin $B$ action to ensure that no testis-specific vasculature is formed (Yao et al. 2004). To date, it is not clear whether the effect of Wnt4 on Fst and endothelial cells is direct or indirect. In Rspo1-deficient XX gonads, Wnt4 and Fst expressions are abolished. The maintenance of Rspo1 expression in Wnt4-deficient gonads indicates that the appearance of the coelomic vessel is not a direct effect of Rspo1 (Chassot et al. 2008a). Therefore, it appears that Rspo1, Wnt4, and Fst have an epistatic relationship during ovarian development, with Rspo1 acting at the top of this genetic cascade. In accordance with this model, XX Rspo1Wnt4-deficient mice (double mutant $\mathrm{Rspo1}^{-1-}$; $W n t 4^{-1-}$ mice) are not more severely affected in their phenotypes than the single XX Rspo1 ${ }^{-1-}$ or Wnt ${ }^{-1-}$ mutants (Chassot et al. 2012), indicating that Rspo1 and Wnt4 act along the same pathway, at least in somatic cells, at the time of sex determination.

\section{Impaired Rspo1 or Wnt4 expression results in ectopic appearance of adrenal-like steroidogenic cells}

The concomitant feature of abnormal vascularization in the XX Rspo $1^{-/-}$or $W n t 4^{-/-}$gonad is the appearance of steroidogenic cells expressing markers such as

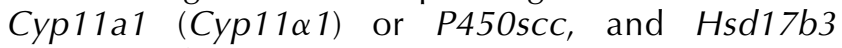
(Hsd17ß3) from $12.5 \mathrm{dpc}$ onwards (Jeays-Ward et al. 2003, Chassot et al. 2008a). In addition, Cyp21a1 (Cyp21), a marker of adrenal steroidogenic cells, is also expressed in the $W n t 4^{-/-}$mutant ovaries, suggesting that these ectopic steroidogenic cells migrate from the neighboring adrenals into the gonad in the absence of Wnt4 (Heikkila et al. 2002, Jeays-Ward et al. 2003). The origin of these cells is not as clear in the $X X$ Rspo $^{-1-}$ mutants, where Cyp21a1 does not seem to be expressed (Lavery et al. 2012). In the XX Wnt4 ${ }^{-1-}$ mutant ovaries, testosterone is produced from $12.5 \mathrm{dpc}$ onwards and several genes encoding enzymes regulating steroidogenesis (Hsd17b1, Hsd17b3, and Cyp11a1) are upregulated (Heikkila et al. 2002). Similarly, Hsd17b3 and Cyp11a1 are strongly upregulated in the $R s p o 1^{-1-}$ mutant (Chassot et al. 2008a). It is likely that these steroidogenic cells produce enough hormones to stimulate the development of epididymis, vas deferens, and hypoplastic seminal vesicles in both mutant situations.

\section{RSPO1, WNT4, and the sex determination of female germ cells}

Although gonadal somatic cells are specified in situ within the developing gonad, the primordial germ cell precursors, future spermatocytes and oocytes, are committed to the germ cell lineage much earlier during embryonic development. Commitment occurs at $\sim 6.5$ $\mathrm{dpc}$ in mice, in the proximal epiblast. Subsequently, germ cells migrate from the allantois through the primitive forming gut to reach and colonize the gonads between 10.5 and $11.0 \mathrm{dpc}$. Once they have reached their destination, they proliferate and initiate divergent sexual differentiation programs depending on their somatic environment, as well as on intrinsic signals (reviewed by Kocer et al. (2009)). Thus, at $\sim 13.5 \mathrm{dpc}$ for female embryos, germ cells progressively enter meiosis, whereas they become quiescent in male embryos at $\sim 14.5$ dpc. Reinitiation of proliferation, differentiation, 
and meiosis occurs in males only after birth, at the onset of puberty.

Time- and sex-specific activation of several genes controls these different events (for a review, see Kocer et al. (2009)). Both Rspo1 and Wnt4 mutants display defects in germ cell development (see below).

\section{RSPO1 regulates proliferation while WNT4 acts as a survival factor in female germ cells}

The Rspo1-deficient XX gonad is characterized by a reduced number of germ cells already evidenced at 12.5 $\mathrm{dpc}$ and caused by a decrease in germ cell proliferation (Chassot et al. 2011). This is not surprising as Rspo1 has been shown previously to stimulate the proliferation of crypt cells (intestinal progenitor cells) in gain-of-function experiments (Kim et al. 2005). However, proliferation affects only about half of the germ cells and remains partial in Rspo1 mutant mice, indicating that RSPO1 is not the only factor controlling the cell cycle of female germ cells. Interestingly, at $16.5 \mathrm{dpc}$, germ cells in the Rspo1-mutant ovary resemble G0-G1-arrested gonocytes, and thus are similar to male germ cells at the same stage (Chassot et al. 2011). This suggests that Rspo1 is also required for germ cell sex determination. Again, this is an incomplete phenotype, suggesting that Rspo1 is not the only factor implicated in ovarian germ cell fate. This demonstrates that RSPO1 is likely to affect germ cells in two ways: i) it stimulates their proliferation and ii) it inhibits their entry into a quiescent phase.

In contrast to the Rspo1-deficient ovary, the number of germ cells in the $W n t 4^{-1-}$ ovary is very similar to that of WT XX gonads between 11.5 and $15.5 \mathrm{dpc}$ (Yao et al. 2004), indicating that they proliferate normally.

Germ cell apoptosis is considered to be a normal process in ovarian development. It is restricted to the medullar region of the ovary and occurs at $\sim 16.5 \mathrm{dpc}$ in the developing gonad in mice (De Felici et al. 2005). This apoptosis contributes to eliminating oocytes having undergone meiotic defects. Germ cell death also occurs in case of somatic defects, as these supporting cells are crucial for germ cell survival. At $16.5 \mathrm{dpc}$, in the XX Wnt4-deficient gonad, germ cells undergo massive apoptosis throughout the entire gonad, with $\sim 90 \%$ being lost at this stage, compared with $30 \%$ in a WT gonad (Yao et al. 2004). By contrast, no increase in apoptosis was detected in the germ cells of Rspo1 mutant gonads before birth. Thus, $17.5 \mathrm{dpc} R s p o 1^{-1-}$ ovaries display much higher germ cell numbers compared with Wnt4 ${ }^{-1-}$ ovaries, and these germ cells are distributed throughout the entire gonad (Chassot et al. 2011, Maatouk et al. 2013). This indicates that Wnt4 is required for female germ cell survival, unlike Rspo1. In addition, this suggests that downregulation of Wnt4 in Rspo1 KO gonads is not complete, and that persistently low levels of Wnt4 may be sufficient to support germ cell survival (Chassot et al. 2008a, Tomizuka et al. 2008).

\section{RSPO1 and WNT4 regulate meiosis entry of female germ cells, potentially through distinct signaling pathways}

Loss of Rspo1 expression also impairs germ cell entry into meiosis (Chassot et al. 2011), and at 14.5 dpc, different germ cell populations can be observed in the mutant XX gonad: about half of the germ cells still express premeiotic and meiotic markers such as Stra8 and Ctdspl (Sycp3). The other half expresses markers of pluripotency, such as Pou5f1 (Oct4), or of quiescence in male germ cells, including Nanos2 and Dnmt3L. In the Wnt4 mutant gonads, the expression of Stra8 is also weak while the expression of Pou5f1 is maintained at $14.5 \mathrm{dpc}$, indicating a delay in meiosis entry (Naillat et al. 2010). However, the number of meiotic germ cells in the $\mathrm{Wnt}^{-1-}$ ovaries is normal when compared with a WT ovary at $15.5 \mathrm{dpc}$ (Yao et al. 2004) and surviving germ cells usually express meiotic markers (Maatouk et al. 2013), before undergoing apoptosis through increasing Activin $\beta$ b expression (Liu et al. 2010). The precise mechanisms of how Rspo1 and Wnt4 affect meiosis entry remain yet to be elucidated.

The retinoic acid (RA) pathway is a key regulator of meiosis entry and ectopic addition of exogenous RA on cultured testis stimulates premature meiosis entry and induces Stra8 expression (Bowles et al. 2006, Koubova et al. 2006). Stimulated by retinoic acid 8 (STRA8) gene is necessary for DNA replication preceding meiosis. Despite these convincing in vitro data, a study aiming to monitor the endogenous role of RA in fetal mouse ovary in vivo reported that $\mathrm{RA}$ is required to induce neither Stra8 nor meiosis (Kumar et al. 2011). Cyp26B1 is a RA-metabolizing cytochrome P450 enzyme expressed in the male embryonic gonad from $12.5 \mathrm{dpc}$ onwards and absent from the ovary. In XY mice deficient for Cyp26b1 (Cyp26b1 ${ }^{-1-}$ mice), germ cells prematurely enter into meiosis only to undergo massive apoptosis from 13.5 dpc onwards, despite generally normal Sertoli and Leydig cell specification (MacLean et al. 2007). Thus, CYP26B1 appears to maintain low RA levels in the male embryonic gonad, in order to inhibit entry of germ cells into meiosis and prevent their apoptosis.

Stra8 is downregulated in the Rspo1 ${ }^{-1-} \mathrm{XX}$ gonad, while Cyp26b1 is not upregulated (Chassot et al. 2011). The absence of Cyp26b1 expression suggests that RA is usually present in mutant $R s p o 1^{-/-}$gonad and that the reduced expression of Stra8 is independent of RA. Nevertheless, further experiments using RA reporter assays are required to confirm definitively RA presence in mutant gonads. It has been recently shown that germ cell differentiation and entry into meiosis are two dissociable events that contribute to the development of a functional oocyte (Dokshin et al. 2013). We currently hypothesize that Rspo1 participates in establishing female germ cell identity, allowing germ cells to become competent to respond to meiotic signals. 
Another hypothesis would be that RA regulates RSPO1 signaling in the developing ovary to promote meiotic gene expression. Further experiments will be required to analyze the relative importance of the two pathways and determine their relationship.

\section{RSPO1, WNT4, and $\beta$-catenin signaling in the female germ cell: transcriptional activity and cell adhesion}

Canonical $\beta$-catenin signaling is activated in XX germ cells, as evidenced by Axin2 expression (Chassot et al. 2011, Jameson et al. 2012a). The active form of CTNNB1 and its transcriptional activity detected in the nuclei of control XX germ cells are lost in germ cells of the Rspo1 $^{-/-}$mutant ovary. Thus, RSPO1 appears to activate canonical $\beta$-catenin signaling in both somatic cells and germ cells of the ovary (Chassot et al. 2011). Consistent with this model, RSPO1 protein is detected on the membrane of both cell types (Kocer et al. 2008, Smith et al. 2008), suggesting that CTNNB1 is directly activated in female germ cells to regulate their fate. Consistent with this hypothesis, germ cells of the XX embryos normally enter meiosis when Ctnnb1 is specifically ablated in somatic cells of the developing

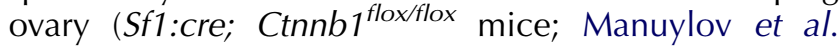
2008, Liu et al. 2009). This suggests that WNT/ $\beta$-catenin signaling in somatic ovarian cells does not affect germ cell fate. Instead, the intrinsic activation of CTNNB1 within the germ cells contributes to female germ cell fate.

Early gonadal patterning is strictly correlated with the cell-specific membrane expression of CTNNB1 and $\mathrm{CDH}$ (cadherins) in adherent junctions during sex determination (Fleming et al. 2012). In the absence of Rspo1, $\beta$-catenin signaling is downregulated in the nucleus and CTNNB1 seems to be relocalized to the cell membrane, where it may function as an adhesion molecule to organize germ cells in clusters and establish cell-cell contacts, a feature characteristic of testes at the same stage (Chassot et al. 2008a). RSPO1 could also directly act on cell surface adhesion molecules through its thrombospondin 1 domain to regulate germ cell adhesion differentially between $X X$ and $X Y$ gonads. Interestingly, Wnt4-deficient gonads also display enhanced cell-to-cell contacts (Naillat et al. 2010), suggesting that Wnt4 is also involved in cell adhesion. Whether RSPO1 and WNT4 directly regulate the expression and/or localization of cell adhesion molecules or whether this increased adhesion is a consequence of an abnormal germ cell identity remains yet to be investigated.

\section{Rspo1/Wnt4 pathways prevent pro-spermatogonia differentiation and sex reversal, in turn}

It has been demonstrated that the decision of germ cells to enter meiosis or to become quiescent depends on their somatic environment (McLaren 1991). Conversely, the involvement of germ cells in the differentiation of supporting cells is less documented.

In Rspo $1^{-/-}$and $\mathrm{Wnt}^{-/-}$mutant ovaries, Pou5f1 expression is maintained as it is in quiescent male germ cells, and the expression of Nanos2, a marker of male germ cells, is upregulated (Chassot et al. 2011). This indicates that in both mutants, germ cells have undergone abnormal differentiation. In addition, germ cells of the $\mathrm{Rspo1}^{-/-}$and $\mathrm{Wnt4^{-/- }}$ ovary have the morphology of G0-G1 arrested gonocytes at 16.5 and $18.5 \mathrm{dpc}$ respectively ((Chassot et al. 2011) and unpublished data). This suggests that, while proliferation is not affected by the absence of $W n t 4$ expression, a proportion of germ cells does not usually progress in meiosis and become quiescent. It is noteworthy that these masculinized germ cells are always found within or in close vicinity of developing testicular cords. However, these masculinized germ cells differentiate before becoming mature Sertoli cells. This is in contrast to normal gonadal development during which somatic cells determine the sexual fate of germ cells (Adams \& McLaren 2002).

Meiotic germ cells antagonize male development in embryonic mouse ovaries (Yao et al. 2003) and female germ cells exert strict control on their surrounding environment under the influence of RSPO1 and WNT4 (Maatouk et al. 2013). Thus, Wnt4-deficient as well as Rspo1-deficient ovaries fail to undergo sex reversal, when germ cells are depleted from the gonad at midgestation by bisulfan treatment (Maatouk et al. 2013). This implies that abnormally differentiated germ cells of these mutants participate in Sertoli cell differentiation and sex reversal. Moreover, the improvement of cell-cell contacts through sex-specific localization of adhesion molecules such as CTNNB1 and CDH1 (E-cadherin) may play a role in this process. Thus far, the signals generated by germ cells upon RSPO1 and WNT4 action and the pathways induced by these signals are unknown.

\section{Lack of Rspo1 or Wnt4 triggers Sertoli cell differentiation around birth}

In the developing ovary, pre-granulosa cells are usually in a quiescent state: they are mitotically arrested and they express cell cycle inhibitors such as p2 $7^{\text {kip } 1}$. In pubescent females and throughout reproductive life, quiescent pre-granulosa cells are organized in ovarian follicles that resume proliferation when the follicle is recruited and matures (Edson et al. 2009). In Rspo1 and Wnt4 mutant gonads, the pre-granulosa cells are not quiescent and differentiate precociously and transiently into proliferative granulosa cells in an anterior-to-posterior wave across the ovary. Then, approximately at the time of birth, germ cells promote these cells to transdifferentiate into Sertoli cells (Maatouk et al. 2013) that, with the onset of Sox9 expression, form tubular structures reminiscent of seminiferous tubules (Vainio 
et al. 1999, Chassot et al. 2008a; Fig. 2). Surprisingly, this transdifferentiation can still occur in the absence of Sry or Sox9, indicating that other genes can induce femaleto-male sex reversal (Lavery et al. 2012). Together, these data indicate that Rspo1 and Wnt4 are involved in maintaining the immature progenitor state of the ovarian supporting cells.

\section{Rspo1, Wnt4, and Foxl2 relationship in ovarian development}

Mutations in FOXL2 in humans lead to blepharophimosis/ptosis/epicanthus inversus syndrome (BPES), an autosomal dominant genetic disorder characterized by drooping eyelids and/or premature ovarian failure in women (Crisponi et al. 2001). FOXL2 is required for the transition from primordial to primary follicle approximately at the time of birth and Fox/2 $2^{-/-}$mice show progressive apoptosis of functional granulosa cells, leading to follicular depletion and ovary atresia (Schmidt et al. 2004). Interestingly, conditional ablation of Fox/2 in adult mice induces reprograming of granulosa cells into Sertoli cells, demonstrating that maintenance of the sexual identity of supporting cells is determined by the antagonistic action of SOX9 and FOXL2 (Uhlenhaut et al. 2009).

In the embryonic mouse ovary, Fox/2 expression is partly dependent on RSPO1 and CTNNB1 (Manuylov et al. 2008, Auguste et al. 2011), whereas it is normally expressed in the $W_{n t 4^{-/-}}$ovary (Manuylov et al. 2008), suggesting that Fox/2 is expressed in two different somatic cell populations. Moreover, simultaneous deletion of Foxl2 $2^{-1-}$ and $\mathrm{Wnt}^{-1-}$, as well as Foxl $2^{-1-}$ and $R s p o 1^{-1-}$, promotes early female-to-male sex reversal (Ottolenghi et al. 2007, Auguste et al. 2011), indicating that Foxl2 and Rspo1/Wnt4 have

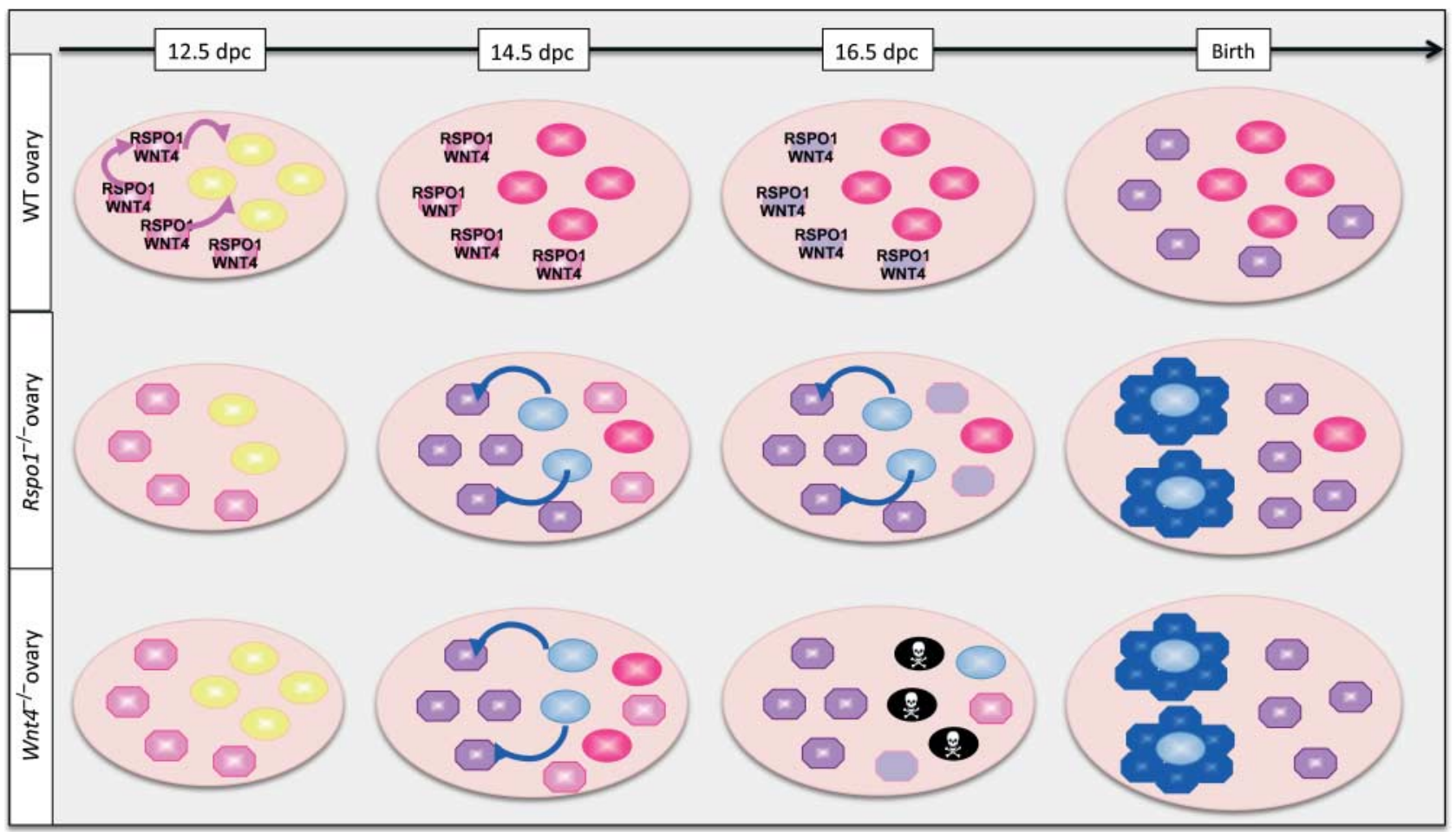

RSPO1 Pre-granulosa cell expressing RSPO1 and WNT4
WNT4

Pre-granulosa cell without RSPO1 or WNT4

Quiescent pregranulosa cell

Granulosa cell
Sertoli cell

Undifferentiated germ cell

Oogonia

Masculinized germ cell

(3) Apoptotic germ cell

Figure 2 Role of Rspo1 and Wnt4 during sexual differentiation. During embryonic development of WT ovaries (top), Rspo1 expression by somatic cells at $12.5 \mathrm{dpc}$ first induces the proliferation, then differentiation of female germ cells into oogonia at 12.5 and 14.5 dpc respectively (pink arrows). Moreover, Rspo1/Wnt4-expressing somatic cells (pre-granulosa cells) become quiescent granulosa cells and resume folliculogenesis approximately at the time of birth. By contrast, in Rspo ${ }^{-1-}$ embryonic ovaries (middle), $\sim 50 \%$ of the germ cell population do not proliferate at $12.5 \mathrm{dpc}$ and become masculinized at $14.5 \mathrm{dpc}$. In $W n t 4^{-1-}$ embryonic ovaries (bottom), the germ cell population proliferates normally, then becomes masculinized at $14.5 \mathrm{dpc}$ and undergoes apoptosis at $16.5 \mathrm{dpc}$. In both mutants, these masculinized germ cells inhibit the entry into quiescence of the pre-granulosa cells (blue arrows), which differentiate early into granulosa cells (Maatouk et al. 2013). These cells then transdifferentiate into Sertoli cells approximately at the time of birth. Some normal granulosa cells and oogonia are still present in the mutant gonads at birth. 
complementary roles during ovarian development. FOXL2 mutations are also sufficient to induce XX sex reversal in the goat (Pailhoux et al. 2001). The different phenotypes observed in Fox 2 mutant mice and goats may indicate a difference in the identity/maturation time of pre-granulosa cells between these species.

\section{R-spondin and Wnt4 genes in ovarian differentiation throughout evolution}

Despite the diversity of 'master sex-determining genes' among species, the key role of WNT signaling in sexual differentiation in humans and mice raises questions about the conservation of this pathway during evolution. Expression and potential roles of WNT genes in other species are largely unclear. WNT4 has been found in various metazoan phyla and the embryonic expression pattern is well conserved throughout vertebrate evolution ((Nicol et al. 2012) for references). RSPOs are expressed in vertebrates and invertebrates, such as hemichordates, chordates, and echinoderms, but screening of Drosophila melanogaster and Caenorhabditis elegans failed to identify any RSPO homolog (Yoon \& Lee 2012). However, the WNT/ $\beta$-catenin pathway is required for male cell fate commitment in the gonad of C. elegans (Kalis et al. 2010).

\section{Mammals}

RSPO1 is upregulated in humans and goats during critical stages of ovarian development. In goats, RSPO1 is expressed in both male and female mesonephroi and the level of expression peaks just before germ cell entry into meiosis (55 dpc; Kocer et al. 2008). In addition to RSPO1, RSPO2 is expressed at the time of folliculogenesis (from $70 \mathrm{dpc}$ until before birth) in goat gonads, while RSPO4 begins to be very faintly expressed in $50 \mathrm{dpc}$ ovaries (Kocer et al. 2008).

In humans, RSPO1 is expressed between 6 and 9 weeks after conception in the fetal ovary (Tomaselli et al. 2011), whereas WNT4 is detected in both the fetal and adult ovary at different follicular stages (Jaaskelainen et al. 2010) as in mice. In marsupials, the WNT4 mRNA level increases after birth, reaching a peak of expression by days 9-13 post partum when the ovarian cortex and medulla become distinguishable (Yu et al. 2006).

\section{Birds}

The amniotes split into the ancestral lineages of mammals and reptiles $\sim 320$ million years ago. In birds, some reptiles, and insects, sex determination depends on the ZZ/ZW chromosomes with ZZ homogametic males and ZW heterogametic females. In ZZ embryos, Rspo 1 and Wnt4 expression levels remain low while Rspo 1 and Wnt4 are specifically expressed in chicken ovaries (Smith et al. 2008). Wnt4 mRNA is detected in oocytes of postnatal chick ovaries. Moreover, Rspo1 expression is downregulated when sex reversal is induced by hormone manipulation of ZW embryos (Lambeth et al. 2013). Thus, Rspo1 and Wnt4 also seem to be key determinants of the female differentiation pathway in the chicken.

\section{Reptiles}

Besides $\mathrm{XY}$ or ZW genetic sex determination, temperature has a dominant role in the establishment and maintenance of sexual fate in some reptiles. The thermosensitive period of the red-eared slider turtle (Trachemys scripta) spans from embryonic stages 14-19/20, during which a $31{ }^{\circ} \mathrm{C}$ temperature of incubation triggers Rspo1 upregulation and the production of female hatchlings (Smith et al. 2008). Moreover, in this species, Wnt4 transcription appears to be upregulated following estrogen signaling (Mork \& Capel 2013).

\section{Amphibians}

In Rana rugosa, Wnt4 is not expressed in a sexually dimorphic fashion in the early stages of gonadal development. Wnt4 is transcribed in the embryos at the late gastrula stage, and its expression is maintained until the undifferentiated gonad differentiates into a testis or an ovary (Oshima et al. 2005).

\section{Teleost fishes}

In mammals, testes and ovaries retain the ability to transdifferentiate in adult life, as documented using mouse mutants (Uhlenhaut et al. 2009, Matson et al. 2011). The plasticity of the adult gonad is most evident in fish species that spontaneously change sex in adult life, shifting from male to female (protandrous) or female to male (protogynous). In the protandrous Black Porgy (Acanthopagrus schlegeli), wnt4 expression is increased during the late ovarian growth and during the transition from male to female (Wu \& Chang 2009), suggesting a conserved role of wnt4 in ovarian development. While in mammals, the transdifferentiation of adult gonads not only affects the somatic cells, but also is associated with sterility; sex-changing fishes retain their fertility. Zebrafish, salmonids, and medakas are teleost fishes, but they have been separated for 115-200 million years. In zebrafish, Rspo1 expression starts to be detected at 30 day post fertilization $(\mathrm{dpf})$ in the somatic cells of the undifferentiated gonads, until $150 \mathrm{dpf}$ in the ovary (granulosa cells and theca cells) and in the testis (Leydig cells), while its expression is present only from 30 to 60 $\mathrm{dpf}$ in female germ cells and until $150 \mathrm{dpf}$ in male germ cells (Zhang et al. 2011). Unlike other teleost fishes, the salmonid rainbow trout (Oncorhynchus mykiss) has a 
third wnt4 gene (Nicol et al. 2012). Protein comparisons with WNT4 from other vertebrates show a high level of amino acid identity $(>80 \%)$. However, wnt4 is not strongly expressed in the ovary during early gonadal differentiation in the rainbow trout. Thus, gonadal differentiation may involve other members of the Wnt gene family. Indeed, other wnt genes have been shown to display a sex-specific expression at different stages of development in the rainbow trout (Nicol \& Guiguen 2011). Moreover, transgenic inhibition of wnt signaling results in male-biased sex ratios, suggesting that Wnt signaling is a conserved key pathway during gonadal differentiation in zebrafish (Sreenivasan et al. 2014). In medaka (Oryzias latipes), Rspo1 and Rspo2 are prominently expressed in both germ cells and somatic cells (Zhou et al. 2012). Their functions in this species remain yet to be clarified. Recently, three genes belonging to the WNT pathways, wnt4, rspo1, and ctnnb1, have been identified in Latimeria menadoensis transcripts and in the Latimeria chalumnae genome, two coelacanths considered to be true 'living fossils' (Forconi et al. 2013).

Despite the diversity of sex determinants in these different phyla, WNT/RSPO1/ $\beta$-catenin signaling appears as an ancient, conserved pathway of ovarian determination.

\section{Remaining questions and prospects}

It is clear today that the RSPO1/WNT/ $\beta$-catenin pathway acts at the top of the ovarian differentiation cascade (Fig. 1). The development of male or female traits appears to be antagonistic, and two key events orient the developing gonad toward a male or a female fate: female (or male) genes need to be expressed and male (or female) genes actively repressed (Jameson et al. $2012 b$; Fig. 1). The molecular mechanisms regulating the expression of Rspo1 and Wnt4 in the bipotential gonad, as well as those involved in their ovary-specific upregulation remain yet to be discovered.

Thus far, it is speculated that Rspo1 and Wnt4 act through the WNT signaling pathway during gonadal development. However, when Ctnnb1 is deleted in

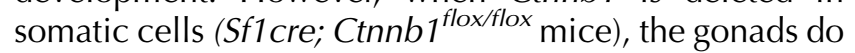
not undergo sex reversal at $18.5 \mathrm{dpc}$ while sex reversal of somatic cells highlighted by Sox9 expression is already noticeable in the Rspo $1^{-1-}$ and $W n t 4^{-/-}$XX gonads at this stage (Chassot et al. 2011, Maatouk et al. 2013). It is likely that sex reversal is promoted by a signal derived from abnormally differentiated germ cells in Rspo1 and Wnt4 mutants, whereas this signal is not produced in

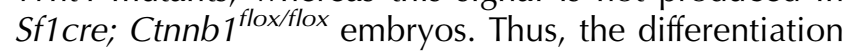
of germ cells is unaffected before they undergo apoptosis in Sf1 cre; Ctnnb $1^{\text {flox/flox }}$ gonads unlike in Rspo $1^{-1-}$ and Wnt4 ${ }^{-1-}$ gonads (Manuylov et al. 2008, Liu et al. 2009, Naillat et al. 2010, Chassot et al. 2011). However, it is not clear as to how germ cells promote sex reversal to occur in Rspo1 and Wnt4 knockout XX gonads (Maatouk et al. 2013). Germ cells might be involved in the early differentiation of granulosa cells via a paracrine signal after which these granulosa cells could transdifferentiate into Sertoli cells. Whether pre-granulosa cells differentiate early in Sf1cre; Ctnnb $1^{\text {flox fllox }} \mathrm{XX}$ gonads has not been investigated thus far.

The most obvious difference between $R s p o 1^{-/-}$and Wnt4 ${ }^{-1-}$ XX mutant embryos is the differentiation of germ cells. Thus, RSPO1 appears to contribute to female germ cell proliferation, while WNT4 rather acts as a survival factor, protecting them from apoptosis, either directly or indirectly. Although both secreted factors are able to activate $W N T / \beta$-catenin signaling, it becomes obvious that they may act through different receptor complexes (LGR/RNF43 for RSPO1 and LRP/Fzl for WNT4) that may be differentially expressed depending on the cell type. Nevertheless, we cannot exclude that these molecules act through distinct signaling pathways in the gonad, which remains yet to be identified. Moreover, their specific receptors and the genetic network they are regulating during sex determination still need to be clarified.

\section{Declaration of interest}

The authors declare that there is no conflict of interest that could be perceived as prejudicing the impartiality of the review.

\section{Funding}

This work was supported by the French Government (National Research Agency, ANR) through the 'Investments for the

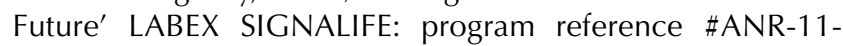
LABX-0028-01 and by L'Agence Nationale pour la Recherche (ANR-09-GENM-009-03 GENIDOV, ANR-13-BSV2-0017-02 ARGONADS) and Association pour la Recherche sur le Cancer (PJA 20131200236).

\section{Acknowledgements}

The authors would like to apologize to all researchers whose work is not listed in the References; unfortunately, we did not have enough space for this. The authors are grateful to Andreas Schedl for his thoughtful contribution to this review and to Catherine Ungar for proofreading.

\section{References}

Adams IR \& McLaren A 2002 Sexually dimorphic development of mouse primordial germ cells: switching from oogenesis to spermatogenesis. Development 129 1155-1164.

Albrecht KH \& Eicher EM 2001 Evidence that Sry is expressed in pre-Sertoli cells and Sertoli and granulosa cells have a common precursor. Developmental Biology 240 92-107. (doi:10.1006/dbio.2001.0438)

Alexandre C, Baena-Lopez A \& Vincent JP 2014 Patterning and growth control by membrane-tethered Wingless. Nature 505 180-185. (doi:10.1038/nature12879) 
Auguste A, Chassot AA, Gregoire EP, Renault L, Pannetier M, Treier M, Pailhoux E \& Chaboissier MC 2011 Loss of R-spondin1 and Foxl2 amplifies female-to-male sex reversal in XX mice. Sexual Development 5 304-317. (doi:10.1159/000334517)

Barolo S 2006 Transgenic Wnt/TCF pathway reporters: all you need is Lef? Oncogene 25 7505-7511. (doi:10.1038/sj.onc.1210057)

Bernard P, Sim H, Knower K, Vilain E \& Harley V 2008 Human SRY inhibits $\beta$-catenin-mediated transcription. International Journal of Biochemistry \& Cell Biology 40 2889-2900. (doi:10.1016/j.biocel.2008.06.006)

Biason-Lauber A, Konrad D, Navratil F \& Schoenle EJ 2004 A WNT4 mutation associated with Müllerian-duct regression and virilization in a 46,XX woman. New England Journal of Medicine 351 792-798. (doi:10.1056/NEJMoa040533)

Blaydon DC, Ishii Y, O'Toole EA, Unsworth HC, Teh MT, Ruschendorf F, Sinclair C, Hopsu-Havu VK, Tidman N, Moss C et al. 2006 The gene encoding R-spondin 4 (RSPO4), a secreted protein implicated in Wnt signaling, is mutated in inherited anonychia. Nature Genetics $\mathbf{3 8}$ 1245-1247. (doi:10.1038/ng1883)

Bowles J, Knight D, Smith C, Wilhelm D, Richman J, Mamiya S, Yashiro K, Chawengsaksophak K, Wilson MJ, Rossant J et al. 2006 Retinoid signaling determines germ cell fate in mice. Science 312 596-600. (doi:10.1126/science.1125691)

Burn SF, Webb A, Berry RL, Davies JA, Ferrer-Vaquer A, Hadjantonakis AK, Hastie ND \& Hohenstein P 2011 Calcium/NFAT signalling promotes early nephrogenesis. Developmental Biology 352 288-298. (doi:10.1016/j.ydbio.2011.01.033)

Cederroth CR, Pitetti JL, Papaioannou MD \& Nef S 2007 Genetic programs that regulate testicular and ovarian development. Molecular and Cellular Endocrinology 265-266 3-9. (doi:10.1016/j.mce.2006.12.029)

Chaboissier MC, Kobayashi A, Vidal VI, Lutzkendorf S, van de Kant HJ, Wegner M, de Rooij DG, Behringer RR \& Schedl A 2004 Functional analysis of Sox8 and Sox9 during sex determination in the mouse. Development 131 1891-1901. (doi:10.1242/dev.01087)

Chassot AA, Ranc F, Gregoire EP, Roepers-Gajadien HL, Taketo MM, Camerino G, de Rooij DG, Schedl A \& Chaboissier MC 2008a Activation of $\beta$-catenin signaling by Rspo1 controls differentiation of the mammalian ovary. Human Molecular Genetics 17 1264-1277. (doi:10.1093/hmg/ddn016)

Chassot AA, Gregoire EP, Magliano M, Lavery R \& Chaboissier MC $2008 b$ Genetics of ovarian differentiation: Rspo1, a major player. Sexual Development 2 219-227. (doi:10.1159/000152038)

Chassot AA, Gregoire EP, Lavery R, Taketo MM, de Rooij DG, Adams IR \& Chaboissier MC 2011 RSPO1/ $\beta$-catenin signaling pathway regulates oogonia differentiation and entry into meiosis in the mouse fetal ovary. PLOS ONE 6 e25641. (doi:10.1371/journal.pone.0025641)

Chassot AA, Bradford ST, Auguste A, Gregoire EP, Pailhoux E, de Rooij DG, Schedl A \& Chaboissier MC 2012 WNT4 and RSPO1 together are required for cell proliferation in the early mouse gonad. Development 139 4461-4472. (doi:10.1242/dev.078972)

Chua AW, Ma D, Gan SU, Fu Z, Han HC, Song C, Sabapathy K \& Phan TT 2011 The role of R-spondin2 in keratinocyte proliferation and epidermal thickening in keloid scarring. Journal of Investigative Dermatology 131 644-654. (doi:10.1038/jid.2010.371)

Cook MS, Munger SC, Nadeau JH \& Capel B 2011 Regulation of male germ cell cycle arrest and differentiation by DND1 is modulated by genetic background. Development 138 23-32. (doi:10.1242/dev.057000)

Cool J, DeFalco TJ \& Capel B 2011 Vascular-mesenchymal cross-talk through Vegf and Pdgf drives organ patterning. PNAS 108 167-172. (doi:10.1073/pnas.1010299108)

Crisponi L, Deiana M, Loi A, Chiappe F, Uda M, Amati P, Bisceglia L, Zelante L, Nagaraja R, Porcu S et al. 2001 The putative forkhead transcription factor FOXL2 is mutated in blepharophimosis/ptosis/epicanthus inversus syndrome. Nature Genetics 27 159-166. (doi:10.1038/ 84781)

De Felici M, Klinger FG, Farini D, Scaldaferri ML, Iona S \& Lobascio M 2005 Establishment of oocyte population in the fetal ovary: primordial germ cell proliferation and oocyte programmed cell death. Reproductive Biomedicine Online 10 182-191. (doi:10.1016/S14726483(10)60939-X)

Dokshin GA, Baltus AE, Eppig JJ \& Page DC 2013 Oocyte differentiation is genetically dissociable from meiosis in mice. Nature Genetics $\mathbf{4 5}$ 877-883. (doi:10.1038/ng.2672)
Edson MA, Nagaraja AK \& Matzuk MM 2009 The mammalian ovary from genesis to revelation. Endocrine Reviews 30 624-712. (doi:10.1210/er. 2009-0012)

Fafilek B, Krausova M, Vojtechova M, Pospichalova V, Tumova L, Sloncova E, Huranova M, Stancikova J, Hlavata A, Svec J et al. 2013 Troy, a tumor necrosis factor receptor family member, interacts with Igr5 to inhibit wnt signaling in intestinal stem cells. Gastroenterology $\mathbf{1 4 4}$ 381-391. (doi:10.1053/j.gastro.2012.10.048)

Fleming A, Ghahramani N, Zhu MX, Delot EC \& Vilain E 2012 Membrane $\beta$-catenin and adherens junctions in early gonadal patterning. Developmental Dynamics 241 1782-1798. (doi:10.1002/dvdy.23870)

Forconi M, Canapa A, Barucca M, Biscotti MA, Capriglione T, Buonocore F, Fausto AM, Makapedua DM, Pallavicini A, Gerdol M et al. 2013 Characterization of sex determination and sex differentiation genes in Latimeria. PLOS ONE 8 e56006. (doi:10.1371/journal.pone.0056006)

Fujimoto Y, Tanaka SS, Yamaguchi YL, Kobayashi H, Kuroki S, Tachibana M, Shinomura M, Kanai Y, Morohashi K, Kawakami K et al. 2013 Homeoproteins six 1 and six4 regulate male sex determination and mouse gonadal development. Developmental Cell 26 416-430. (doi:10.1016/j.devcel.2013.06.018)

Glinka A, Dolde C, Kirsch N, Huang YL, Kazanskaya O, Ingelfinger D, Boutros M, Cruciat CM \& Niehrs C 2011 LGR4 and LGR5 are R-spondin receptors mediating $\mathrm{Wnt} / \beta$-catenin and $\mathrm{Wnt} / \mathrm{PCP}$ signalling. $E M B O$ Reports 12 1055-1061. (doi:10.1038/embor.2011.175)

Gore AV, Swift MR, Cha YR, Lo B, McKinney MC, Li W, Castranova D, Davis A, Mukouyama YS \& Weinstein BM 2011 Rspo1/Wnt signaling promotes angiogenesis via Vegfc/Vegfr3. Development 138 4875-4886. (doi:10.1242/dev.068460)

Heikkila M, Peltoketo H, Leppaluoto J, Ilves M, Vuolteenaho O \& Vainio S 2002 Wnt-4 deficiency alters mouse adrenal cortex function, reducing aldosterone production. Endocrinology 143 4358-4365. (doi:10.1210/ en.2002-220275)

Jaaskelainen $M$, Prunskaite-Hyyrylainen $\mathbf{R}$, Naillat $F$, Parviainen $\mathbf{H}$, Anttonen M, Heikinheimo M, Liakka A, Ola R, Vainio S, Vaskivuo TE et al. 2010 WNT4 is expressed in human fetal and adult ovaries and its signaling contributes to ovarian cell survival. Molecular and Cellular Endocrinology 317 106-111. (doi:10.1016/j.mce.2009.11.013)

Jameson SA, Natarajan A, Cool J, DeFalco T, Maatouk DM, Mork L, Munger SC \& Capel B 2012a Temporal transcriptional profiling of somatic and germ cells reveals biased lineage priming of sexual fate in the fetal mouse gonad. PLoS Genetics 8 e1002575. (doi:10.1371/ journal.pgen.1002575)

Jameson SA, Lin YT \& Capel B $2012 b$ Testis development requires the repression of Wnt4 by Fgf signaling. Developmental Biology 370 24-32. (doi:10.1016/j.ydbio.2012.06.009)

Jeays-Ward K, Hoyle C, Brennan J, Dandonneau M, Alldus G, Capel B \& Swain A 2003 Endothelial and steroidogenic cell migration are regulated by WNT4 in the developing mammalian gonad. Development 130 3663-3670. (doi:10.1242/dev.00591)

Jost A 1947 Recherche sur la différenciation sexuelle de l'embryon de lapin. Archives d'Anatomie Microscopique et de Morphologie Expérimentale 271-315.

Kalis AK, Kroetz MB, Larson KM \& Zarkower D 2010 Functional genomic identification of genes required for male gonadal differentiation in Caenorhabditis elegans. Genetics 185 523-535. (doi:10.1534/genetics. 110.116038)

Kamata T, Katsube K, Michikawa M, Yamada M, Takada S \& Mizusawa $\mathbf{H}$ 2004 R-spondin, a novel gene with thrombospondin type 1 domain, was expressed in the dorsal neural tube and affected in Wnts mutants. Biochimica et Biophysica Acta 1676 51-62. (doi:10.1016/j.bbaexp. 2003.10.009)

Karl J \& Capel B 1998 Sertoli cells of the mouse testis originate from the coelomic epithelium. Developmental Biology 203 323-333. (doi:10. 1006/dbio.1998.9068)

Kazanskaya O, Glinka A, del Barco Barrantes I, Stannek P, Niehrs C \& Wu W 2004 R-Spondin2 is a secreted activator of Wnt/ $\beta$-catenin signaling and is required for Xenopus myogenesis. Developmental Cell 7 525-534. (doi:10.1016/j.devcel.2004.07.019)

Kazanskaya O, Ohkawara B, Heroult M, Wu W, Maltry N, Augustin HG \& Niehrs C 2008 The Wnt signaling regulator R-spondin 3 promotes angioblast and vascular development. Development 135 3655-3664. (doi:10.1242/dev.027284) 
Kim KA, Kakitani M, Zhao J, Oshima T, Tang T, Binnerts M, Liu Y, Boyle B, Park E, Emtage P et al. 2005 Mitogenic influence of human R-spondin1 on the intestinal epithelium. Science 309 1256-1259. (doi:10.1126/ science.1112521)

Kim Y, Kobayashi A, Sekido R, Dinapoli L, Brennan J, Chaboissier MC, Poulat F, Behringer RR, Lovell-Badge R \& Capel B 2006 Fgf9 and wnt4 act as antagonistic signals to regulate mammalian sex determination. PLoS Biology 4 e187. (doi:10.1371/journal.pbio.0040187)

Kocer A, Pinheiro I, Pannetier M, Renault L, Parma P, Radi O, Kim KA, Camerino G \& Pailhoux E 2008 R-spondin1 and FOXL2 act into two distinct cellular types during goat ovarian differentiation. BMC Developmental Biology 8 36. (doi:10.1186/1471-213X-8-36)

Kocer A, Reichmann J, Best D \& Adams IR 2009 Germ cell sex determination in mammals. Molecular Human Reproduction 15 205-213. (doi:10.1093/molehr/gap008)

Koo BK, Spit M, Jordens I, Low TY, Stange DE, van de Wetering M, van Es JH, Mohammed S, Heck AJ, Maurice MM et al. 2012 Tumour suppressor RNF43 is a stem-cell E3 ligase that induces endocytosis of Wnt receptors. Nature 488 665-669. (doi:10.1038/nature11308)

Koubova J, Menke DB, Zhou Q, Capel B, Griswold MD \& Page DC 2006 Retinoic acid regulates sex-specific timing of meiotic initiation in mice. PNAS 103 2474-2479. (doi:10.1073/pnas.0510813103)

Kumar S, Chatzi C, Brade T, Cunningham TJ, Zhao X \& Duester G 2011 Sex-specific timing of meiotic induction is regulated by Cyp26b1 independent of retinoic acid signalling. Nature Communications 2 151. (doi:10.1038/ncomms1136)

Lambeth LS, Cummins DM, Doran TJ, Sinclair AH \& Smith CA 2013 Overexpression of aromatase alone is sufficient for ovarian development in genetically male chicken embryos. PLOS ONE 8 e68362. (doi:10. 1371/journal.pone.0068362)

de Lau W, Barker N, Low TY, Koo BK, Li VS, Teunissen H, Kujala P, Haegebarth A, Peters PJ, van de Wetering M et al. 2011 Lgr5 homologues associate with Wnt receptors and mediate R-spondin signalling. Nature 476 293-297. (doi:10.1038/nature10337)

de Lau W, Peng WC, Gros P \& Clevers H 2014 The R-spondin/Lgr5/Rnf43 module: regulator of Wnt signal strength. Genes and Development $\mathbf{2 8}$ 305-316. (doi:10.1101/gad.235473.113)

Lavery R, Chassot AA, Pauper E, Gregoire EP, Klopfenstein M, de Rooij DG, Mark M, Schedl A, Ghyselinck NB \& Chaboissier MC 2012 Testicular differentiation occurs in absence of R-spondin1 and Sox9 in mouse sex reversals. PLOS Genetics 8 e1003170. (doi:10.1371/journal.pgen. 1003170)

Liu CF, Bingham N, Parker K \& Yao HH 2009 Sex-specific roles of $\beta$-catenin in mouse gonadal development. Human Molecular Genetics 18 405-417. (doi:10.1093/hmg/ddn362)

Liu CF, Parker K \& Yao HH 2010 WNT4/ $\beta$-catenin pathway maintains female germ cell survival by inhibiting activin $\beta B$ in the mouse fetal ovary. PLOS ONE 5 e10382. (doi:10.1371/journal.pone.0010382)

Maatouk DM, DiNapoli L, Alvers A, Parker KL, Taketo MM \& Capel B 2008 Stabilization of $\beta$-catenin in $\mathrm{XY}$ gonads causes male-to-female sexreversal. Human Molecular Genetics 17 2949-2955. (doi:10.1093/hmg/ ddn193)

Maatouk DM, Mork L, Chassot AA, Chaboissier MC \& Capel B 2013 Disruption of mitotic arrest precedes precocious differentiation and transdifferentiation of pregranulosa cells in the perinatal Wnt4 mutant ovary. Developmental Biology 383 295-306. (doi:10.1016/j.ydbio. 2013.08.026)

MacLean G, Li H, Metzger D, Chambon P \& Petkovich M 2007 Apoptotic extinction of germ cells in testes of Cyp26b1 knockout mice. Endocrinology 148 4560-4567. (doi:10.1210/en.2007-0492)

Mandel H, Shemer R, Borochowitz ZU, Okopnik M, Knopf C, Indelman M, Drugan A, Tiosano D, Gershoni-Baruch R, Choder M et al. 2008 SERKAL syndrome: an autosomal-recessive disorder caused by a loss-of-function mutation in WNT4. American Journal of Human Genetics 82 39-47. (doi:10.1016/j.ajhg.2007.08.005)

Manuylov NL, Smagulova FO, Leach L \& Tevosian SG 2008 Ovarian development in mice requires the GATA4-FOG2 transcription complex. Development 135 3731-3743. (doi:10.1242/dev.024653)

Matson CK, Murphy MW, Sarver AL, Griswold MD, Bardwell VJ \& Zarkower D 2011 DMRT1 prevents female reprogramming in the postnatal mammalian testis. Nature 476 101-104. (doi:10.1038/ nature10239)
McLaren A 1991 Development of the mammalian gonad: the fate of the supporting cell lineage. BioEssays 13 151-156. (doi:10.1002/bies. 950130402)

Mork L \& Capel B 2013 Conserved action of $\beta$-catenin during female fate determination in the red-eared slider turtle. Evolution \& Development 15 96-106. (doi:10.1111/ede.12020)

Naillat F, Prunskaite-Hyyrylainen R, Pietila I, Sormunen R, Jokela T, Shan J \& Vainio SJ 2010 Wnt4/5a signalling coordinates cell adhesion and entry into meiosis during presumptive ovarian follicle development. Human Molecular Genetics 19 1539-1550. (doi:10.1093/hmg/ddq027)

Nicol B \& Guiguen Y 2011 Expression profiling of Wnt signaling genes during gonadal differentiation and gametogenesis in rainbow trout. Sexual Development 5 318-329. (doi:10.1159/000334515)

Nicol B, Guerin A, Fostier A \& Guiguen Y 2012 Ovary-predominant wnt4 expression during gonadal differentiation is not conserved in the rainbow trout (Oncorhynchus mykiss). Molecular Reproduction and Development 79 51-63. (doi:10.1002/mrd.21404)

Niehrs C 2012 The complex world of WNT receptor signalling. Nature Reviews. Molecular Cell Biology 13 767-779. (doi:10.1038/ nrm3470)

Oshima Y, Hayashi T, Tokunaga S \& Nakamura M 2005 Wnt4 expression in the differentiating gonad of the frog Rana rugosa. Zoological Science 22 689-693. (doi:10.2108/zsj.22.689)

Ottolenghi C, Pelosi E, Tran J, Colombino M, Douglass E, Nedorezov T, Cao A, Forabosco A \& Schlessinger D 2007 Loss of Wnt4 and Foxl2 leads to female-to-male sex reversal extending to germ cells. Human Molecular Genetics 16 2795-2804. (doi:10.1093/hmg/ddm235)

Pailhoux E, Vigier B, Chaffaux S, Servel N, Taourit S, Furet JP, Fellous M, Grosclaude F, Cribiu EP, Cotinot C et al. 2001 A 11.7-kb deletion triggers intersexuality and polledness in goats. Nature Genetics 29 453-458. (doi:10.1038/ng769)

Parma P, Radi O, Vidal V, Chaboissier MC, Dellambra E, Valentini S, Guerra L, Schedl A \& Camerino G 2006 R-spondin1 is essential in sex determination, skin differentiation and malignancy. Nature Genetics 38 1304-1309. (doi:10.1038/ng1907)

Pitetti JL, Calvel P, Romero Y, Conne B, Truong V, Papaioannou MD, Schaad O, Docquier M, Herrera PL, Wilhelm D et al. 2013 Insulin and IGF1 receptors are essential for $X X$ and $X Y$ gonadal differentiation and adrenal development in mice. PLoS Genetics 9 e1003160. (doi:10.1371/ journal.pgen.1003160)

Schmahl J, Kim Y, Colvin JS, Ornitz DM \& Capel B 2004 Fgf9 induces proliferation and nuclear localization of FGFR2 in Sertoli precursors during male sex determination. Development 131 3627-3636. (doi:10.1242/dev.01239)

Schmidt D, Ovitt CE, Anlag K, Fehsenfeld S, Gredsted L, Treier AC \& Treier M 2004 The murine winged-helix transcription factor Foxl2 is required for granulosa cell differentiation and ovary maintenance. Development 131 933-942. (doi:10.1242/dev.00969)

Sekido R \& Lovell-Badge R 2008 Sex determination involves synergistic action of SRY and SF1 on a specific Sox9 enhancer. Nature 453 930-934. (doi:10.1038/nature06944)

Sinclair AH, Berta P, Palmer MS, Hawkins JR, Griffiths BL, Smith MJ, Foster JW, Frischauf AM, Lovell-Badge R \& Goodfellow PN 1990 A gene from the human sex-determining region encodes a protein with homology to a conserved DNA-binding motif. Nature 346 240-244. (doi:10.1038/346240a0)

Smith CA, Shoemaker CM, Roeszler KN, Queen J, Crews D \& Sinclair AH 2008 Cloning and expression of R-Spondin1 in different vertebrates suggests a conserved role in ovarian development. BMC Developmental Biology 8 72. (doi:10.1186/1471-213X-8-72)

Sreenivasan R, Jiang J, Wang X, Bartfai R, Kwan HY, Christoffels A \& Orban L 2014 Gonad differentiation in zebrafish is regulated by the canonical Wnt signaling pathway. Biology of Reproduction 9045. (doi:10.1095/biolreprod.113.110874)

Svingen T \& Koopman P 2013 Building the mammalian testis: origins, differentiation, and assembly of the component cell populations. Genes and Development 27 2409-2426. (doi:10.1101/gad.228080.113)

Tomaselli S, Megiorni F, De Bernardo C, Felici A, Marrocco G, Maggiulli G, Grammatico B, Remotti D, Saccucci P, Valentini F et al. 2008 Syndromic true hermaphroditism due to an R-spondin1 (RSPO1) homozygous mutation. Human Mutation 29 220-226. (doi:10.1002/humu.20665) 
Tomaselli S, Megiorni F, Lin L, Mazzilli MC, Gerrelli D, Majore S, Grammatico P \& Achermann JC 2011 Human RSPO1/R-spondin1 is expressed during early ovary development and augments $\beta$-catenin signaling. PLoS ONE 6 e16366. (doi:10.1371/journal.pone.0016366)

Tomizuka K, Horikoshi K, Kitada R, Sugawara Y, Iba Y, Kojima A, Yoshitome A, Yamawaki K, Amagai M, Inoue A et al. 2008 R-spondin1 plays an essential role in ovarian development through positively regulating Wnt-4 signaling. Human Molecular Genetics 17 1278-1291. (doi:10.1093/hmg/ddn036)

Uhlenhaut NH, Jakob S, Anlag K, Eisenberger T, Sekido R, Kress J, Treier AC, Klugmann C, Klasen C, Holter NI et al. 2009 Somatic sex reprogramming of adult ovaries to testes by FOXL2 ablation. Cell 139 1130-1142. (doi:10.1016/j.cell.2009.11.021)

Vainio S, Heikkila M, Kispert A, Chin N \& McMahon AP 1999 Female development in mammals is regulated by Wnt-4 signalling. Nature 397 405-409. (doi:10.1038/17068)

Warr N, Carre GA, Siggers P, Faleato JV, Brixey R, Pope M, Bogani D, Childers M, Wells S, Scudamore CL et al. 2012 Gadd45 $\gamma$ and Map3k4 interactions regulate mouse testis determination via p38 MAPK-mediated control of Sry expression. Developmental Cell 23 1020-1031. (doi:10. 1016/j.devcel.2012.09.016)

Wu GC \& Chang CF 2009 wnt4 Is associated with the development of ovarian tissue in the protandrous black Porgy, Acanthopagrus schlegeli. Biology of Reproduction 81 1073-1082. (doi:10.1095/biolreprod.109. 077362)

Wu C, Qiu S, Lu L, Zou J, Li WF, Wang O, Zhao H, Wang H, Tang J, Chen L et al. 2014 RSPO2-LGR5 signaling has tumour-suppressive activity in colorectal cancer. Nature Communications 5 3149. (doi:10.1038/ ncomms4149)
Yao HH, DiNapoli L \& Capel B 2003 Meiotic germ cells antagonize mesonephric cell migration and testis cord formation in mouse gonads. Development 130 5895-5902. (doi:10.1242/dev.00836)

Yao HH, Matzuk MM, Jorgez CJ, Menke DB, Page DC, Swain A \& Capel B 2004 Follistatin operates downstream of Wnt4 in mammalian ovary organogenesis. Developmental Dynamics 230 210-215. (doi:10.1002/ dvdy.20042)

Yoon JK \& Lee JS 2012 Cellular signaling and biological functions of R-spondins. Cellular Signalling 24 369-377. (doi:10.1016/j.cellsig.2011. 09.023)

Yu H, Pask AJ, Shaw G \& Renfree MB 2006 Differential expression of WNT4 in testicular and ovarian development in a marsupial. BMC Developmental Biology 6 44. (doi:10.1186/1471-213X-6-44)

Zhang Y, Li F, Sun D, Liu J, Liu N \& Yu Q 2011 Molecular analysis shows differential expression of R-spondin1 in zebrafish (Danio rerio) gonads. Molecular Biology Reports 38 275-282. (doi:10.1007/s11033-0100105-3)

Zhou L, Charkraborty T, Yu X, Wu L, Liu G, Mohapatra S, Wang D \& Nagahama Y 2012 R-spondins are involved in the ovarian differentiation in a teleost, medaka (Oryzias latipes). BMC Developmental Biology 12 36. (doi:10.1186/1471-213X-12-36)

Received 1 April 2014

First decision 12 May 2014

Revised manuscript received 4 August 2014

Accepted 2 September 2014 